\title{
Spinoffs and Firm Policy
}

\author{
Seoungpil Ahn \\ Sogang Business School \\ Sogang University \\ PA706, 35 Baekbeom-ro, Mapo-gu, Seoul 121-742, Korea \\ E-mail: spahn@sogang.ac.kr
}

Received: Nov. 5, 2017 Accepted: Dec. 22, $2017 \quad$ Published: December 24, 2017

doi:10.5296/ajfa.v9i2.12234 URL: https://doi.org/10.5296/ajfa.v9i2.12234

\begin{abstract}
I investigate the nature of reconstructing by examining the changes in firm policies around spinoff. Because the pre-spinoff contract structure is more suitable for larger divisions of firms, separated units experience relatively large changes in contracts following spinoffs. Compared to the post-spinoff parent firms, separated units have lower tendency to pay dividends, lower ownership by CEOs, higher fraction of outside directors, smaller board, younger board members, higher block ownerships, and higher incentive payment. There are significant changes in the firm policies in both high q and low q units, however the market response is more positive for units with higher growth opportunities.
\end{abstract}

Keywords: IPO, Valuation, Holding Company, Ownership Structure, Governance Structure JEL classification: G30; G32; G34 


\section{Introduction}

Previous studies provide limited evidence on the causal relation between board structure and its determinants. Hermalin and Weisbach (2003) argue that board structure and variables that are associated with board structure are jointly determined by past performance. As long as the explanatory variables such as firm size and growth opportunities are reasonably stable over time, board structure remains stable and exhibits path dependence on its past structure. In the case, the change in board structure is more likely affected by economic shocks rather than change in firm specific characteristics.

Denis and Sarin (1999) shows that large change in board structure is typically preceded by fundamental changes in the business conditions, but it is only weakly related to the changes in firm-specific determinants of board structure. Wintoki, Linck, and Netter (2012) argue that board size and composition are affected by past firm performance. Lehn, Patro, and Zhao (2004) provide direct evidence of path dependence showing that lagged board structure is positively correlated with current board structure. Therefore, explicit modeling of the endogeniety is necessary in cross-sectional analysis of the determinants of board structure.

Alternative approach is to examine unique samples relatively free from the endogeniety issue. Boone, Field, Karpoff, and Raheja (2007) address the concern by examining board structure of IPO firms. IPO firms experience significant changes in governance structure to meet the requirement as public firms. Nonetheless, it is unclear whether the board structure at the time of IPO is truly independent from past performance. Because past board structure as private companies is unknown, it is impossible to check path-independence of their sample.

The approach to examine newly emerged companies from spinoffs is similar to Boone, Field, Karpoff, and Raheja (2007) in an effort to find unique sample that are less subject to the endogeniety problem. There are benefits of examining board structure of spunoff units. Firstly, as long as optimal board structure of units is different from that of parent, a spinoff creates an opportunity for newly established spun off units to set up their own board structure which is suitable for units. Second, spunoff units experience significant change in their asset structure over the short period. Therefore, the influence of the changes in firm characteristics on board structure can be easily detected. Third, with pre-spinoff board data, I can examine path dependence of post-spinoff units. Thereby, I can verify assumption on the endogeniety in the sample.

For spinoffs completed during the period of 1993 to 2010, I investigate the nature of reconstructing following spinoffs. Specifically, I examine changes in debt policy, dividend policy, changes in ownership structure and board structure, and compensation policy. Spinoff units represent about $20 \%$ of assets in the combined firms. Since pre-spinoff contract structure is more suitable for larger remaining parents, units experience relatively large changes in contracts following spinoffs. Compared to post-spinoff parents, separated units have lower tendency to pay dividends, lower ownership by CEOs, higher fraction of outside directors, smaller board, younger board members, higher block ownerships, and higher incentive payment. Although I have observed significant changes in contract structure in both high q and low q units, the market response is more positive when spin off units have higher 
growth opportunities. Therefore, the reconstructing benefit of spin-offs exists only when high q units are separated.

\section{Data Description}

Spinoff sample is collected with the following procedure. Initial data of spinoffs is collected from SDC M\&A database. For spinoffs announced and completed during the period of 1993 to 2010, I use Factiva (formerly, Dow Jones Newswire) to verify the spinoff event and identify spinoff announcement date and ex-dividend date. Spinoffs of which related news on spinoff transaction are unavailable from Factiva are discarded. Pre-spinoff firms shall distribute more than $80 \%$ of spinoff units' ownership to be included in the sample and any partial spinoffs or equity carve-outs are excluded. Both spinoffs by single segment firms and multiple-segment firms are included. Following previous studies, spinoffs conducted by financial companies, firms in regulated industries, and foreign companies are excluded. In addition, spinoff firms shall have financial data for both parent and spinoff units on Compustat for at least two years around the spinoff and stock return data on CRSP around the spinoff announcement date. Finally, I require that both parent and spinoff units have proxy statements filed in Lexis-Lexus for two years around the spinoff. The final sample consists of 211 spin-offs

Table 1 reports time profile of spinoffs and data description. Panel A reports the number of completed spinoffs in each year during the period of 1993 to 2010. Panel B is financial characteristics of pre-spinoff firms $\left(\mathrm{P}_{\mathrm{B}}\right)$, post-spinoff parents $\left(\mathrm{P}_{\mathrm{A}}\right)$ and post-spinoff units $\left(\mathrm{U}_{\mathrm{A}}\right)$. Last three columns reports the absolute differences of the financial characteristics among these three groups. All variables are winsorized at 5\% and 95\%. In tables, ****, and *** indicate statistical significance at $10 \%, 5 \%$, and $1 \%$, respectively.

Table 1. Descriptive statistics

Panel A. Time Profile

\begin{tabular}{|c|c|c|c|}
\hline Year & Number of Spinoffs & Year & Number of Spinoffs \\
\hline 1993 & 4 & 2002 & 7 \\
\hline 1994 & 11 & 2003 & 4 \\
\hline 1995 & 10 & 2004 & 8 \\
\hline 1996 & 20 & 2005 & 10 \\
\hline 1997 & 12 & 2006 & 12 \\
\hline 1998 & 14 & 2007 & 15 \\
\hline 1999 & 16 & 2008 & 13 \\
\hline 2000 & 21 & 2009 & 10 \\
\hline 2001 & 13 & 2010 & 211 \\
\hline $\mathrm{N}$ & & & \\
\hline
\end{tabular}


Panel B. Descriptive Statistics

\begin{tabular}{|l|c|c|c|c|c|c|}
\hline & $\mathrm{P}_{\mathrm{B}}$ & $\mathrm{P}_{\mathrm{A}}$ & $\mathrm{U}_{\mathrm{A}}$ & $\begin{array}{c}\text { Difference } \\
\left(\mathrm{P}_{\mathrm{A}}-\mathrm{P}_{\mathrm{B}}\right)\end{array}$ & $\begin{array}{c}\text { Difference } \\
\left(\mathrm{U}_{\mathrm{A}}-\mathrm{P}_{\mathrm{B}}\right)\end{array}$ & $\begin{array}{c}\text { Difference } \\
\left(\mathrm{U}_{\mathrm{A}}-\mathrm{P}_{\mathrm{A}}\right)\end{array}$ \\
\hline \multirow{2}{*}{ Assets } & $5,980.57$ & 5208.45 & 1517.25 & $-423.19^{* *}$ & $-4535.7^{* * *}$ & $-3928.3^{* * *}$ \\
& {$[2,089.51]$} & {$[2086.00]$} & {$[508.86]$} & {$[-64.69]^{* * *}$} & {$[-1579.3]^{* * *}$} & {$[-1316.9]^{* * *}$} \\
\hline \multirow{2}{*}{ Sales } & 5621.47 & 4345.83 & 1300.69 & $-747.27^{* * *}$ & $-4133.1^{* * *}$ & $-3129.5^{* * *}$ \\
& {$[2,574.49]$} & {$[1920.36]$} & {$[571.73]$} & {$[-210.81]^{* * *}$} & {$[-2063.5]^{* * *}$} & {$[-1152.4]^{* * *}$} \\
\hline \multirow{2}{*}{ MtoB } & 1.92 & 1.90 & 2.03 & -0.0023 & 0.1599 & 0.1519 \\
& {$[1.69]$} & {$[1.57]$} & {$[1.66]$} & {$[-0.0167]$} & {$[0.0254]$} & {$[-0.0651]$} \\
\hline \multirow{2}{*}{ ROA } & 0.1525 & 0.1340 & 0.0838 & $-0.0205^{* * *}$ & $-0.0614^{* * *}$ & $-0.0471^{* * *}$ \\
& {$[0.1543]$} & {$[0.1314]$} & {$[0.1310]$} & {$[-0.0148]^{* * *}$} & {$[-0.0225]^{* * *}$} & {$[-0.0064]$} \\
\hline \multirow{2}{*}{ OM } & 0.1603 & 0.1483 & -0.0278 & -0.0088 & $-0.1903^{* * *}$ & $-0.1721^{* * *}$ \\
& {$[0.1552]$} & {$[0.1522]$} & {$[0.1128]$} & {$[0.0000]$} & {$[-0.0364]^{* * *}$} & {$[-0.0346]^{* * *}$} \\
\hline
\end{tabular}

From panel B of table 1, spinoff units are relatively weak segments: smaller in size and lower operating performance. Growth opportunities measured by Market-to-Book (MtoB) is insignificantly different between parents and aunts, but absolute difference is quite large, 1.18 in the mean. This suggests that high variation in the form of spinoffs where some units have higher $\mathrm{q}$ than parents and other units have lower $\mathrm{q}$ than parents. Parents after spinoffs also show higher ROA and operating margin $(\mathrm{OM})$ than those of units.

\section{Empirical Results and Discussion}

Next, I compare announcement period abnormal returns for firms completed spinoffs between 1993 and 2010. Market-Adjusted Returns (MARs) using CRSP Value Weighted Returns are measured in the $(-1,+1)$ days window surrounding the spinoff announcement date. All variables are winsorized at $5 \%$ and $95 \%$. Mean and median differences are tested with t-test and Wilcoxson Signed Rank test. 
Table 2. Announcment abnormal return

\begin{tabular}{|l|c|c|c|}
\hline & $\mathrm{N}$ & Mean MARs & Median MARs \\
\hline Full sample & 211 & $3.54 \%^{* * *}$ & $3.36 \%^{* * *}$ \\
\hline Cross-industry spinoffs at 2-digit SIC & 139 & $3.60 \%^{* * *}$ & $3.45 \%^{* * *}$ \\
\hline Same-industry spinoffs at 2-digit SIC & 72 & $3.42 \%^{* * *}$ & $3.21 \%^{* * *}$ \\
\hline P-Value (Difference) & & 0.89 & 0.87 \\
\hline Cross-industry spinoffs at 3-digit SIC & 166 & $3.75 \%^{* * *}$ & $3.51 \%^{* * *}$ \\
\hline Same-industry spinoffs at 3-digit SIC & 45 & $2.73 \%^{*}$ & $3.19 \%^{* *}$ \\
\hline P-Value (Difference) & & 0.50 & 0.59 \\
\hline Difference in MtoB $>$ top 1/3 & 70 & $3.88 \%^{* * *}$ & $5.15 \%^{* * *}$ \\
\hline Difference in MtoB in the middle & 71 & $3.43 \%^{* * *}$ & $3.01 \%^{* * *}$ \\
\hline Difference in MtoB $<$ bottom 1/3 & 70 & $3.30 \%^{* * *}$ & $3.19 \%^{* * *}$ \\
\hline P-Value (Difference) & & 0.92 & 0.89 \\
\hline Units' MtoB $>$ top 1/3 & 70 & $5.20 \%^{* * *}$ & $5.85 \%^{* * *}$ \\
\hline Units' MtoB in the middle & 71 & $3.87 \%^{* * *}$ & $3.76 \%^{* * *}$ \\
\hline Units' MtoB < bottom 1/3 & 71 & $1.54 \%^{* *}$ & $1.81 \%^{* *}$ \\
\hline P-Value (Difference) & & $0.05^{* *}$ & $0.03^{* *}$ \\
\hline
\end{tabular}

Table 2 reports announcement abnormal return with market adjusted returns (MARs). On average, two-day announcement MARs is $3.54 \%$ which is consistent with the finding in previous literature (see for example, Hite and Owers, 1983; Cusatis, Miles and Woolridge, 1993; Allen, Lummer, McConnell and Reed, 1995). MARs in the cross-industry spinoffs is higher than MARS in the same-industry spinoffs. However, the differences in mean and median MARs are insignificant.

Under the hypothesis that larger difference in growth opportunities between parents and units leads to higher benefits from recontracting, sample firms are divided into three sub-groups based on the absolute difference in Market-to-Book ratios between parents and units. MARs among three-groups are insignificantly different.

Since pre-spinoff contract structure is more suitable for larger remaining parents, units experience relatively large changes in contracts following spinoffs. Therefore, it is possible that the benefit of recontracting is concentrated in spinoff units and those with higher growth opportunities. Thus, I further divide sample firms into three groups based on units' Market-to-Book ratio, which is a measure of growth opportunity. The result shows that announcement returns are higher for spinoffs separating higher q units. Next we investigate whether this larger announcement return reflects recontracting benefits by examining changes in contracts in spunoff units.

In table 3 , I compare contract structure in pre-spinoff firms $\left(\mathrm{P}_{\mathrm{B}}\right)$, post-spinoff parents $\left(\mathrm{P}_{\mathrm{A}}\right)$ and post-spinoff units $\left(\mathrm{U}_{\mathrm{A}}\right)$. Units are experiencing more changes in contracts than parents. 


\section{Macrothink}

Asian Journal of Finance \& Accounting ISSN 1946-052X 2017, Vol. 9, No. 2

Specifically, separated units have relatively lower tendency to pay dividends, lower ownership by CEOs, higher fraction of outside directors, smaller board, younger board members, higher block ownerships, and higher incentive payment. The result confirms that pre-spinoff contract structure is designed to be more suitable for larger remaining parents.

Table 3. Recontracting of parents and units

\begin{tabular}{|c|c|c|c|c|}
\hline & $\mathrm{P}_{\mathrm{B}}$ & $\mathrm{P}_{\mathrm{A}}$ & $\mathrm{U}_{\mathrm{A}}$ & $\begin{array}{c}\text { Difference } \\
\left(\mathrm{U}_{\mathrm{A}}-\mathrm{P}_{\mathrm{A}}\right)\end{array}$ \\
\hline \multicolumn{5}{|l|}{ Debt Policy } \\
\hline Leverage & $\begin{array}{c}0.2449 \\
{[0.2598]}\end{array}$ & $\begin{array}{c}0.2623 \\
{[0.2566]}\end{array}$ & $\begin{array}{c}0.2313 \\
{[0.1889]}\end{array}$ & $\begin{array}{c}-0.0155 \\
{[-0.0111]}\end{array}$ \\
\hline Total Liability/Total Assets & $\begin{array}{c}0.5930 \\
{[0.6002]}\end{array}$ & $\begin{array}{c}0.6207 \\
{[0.6142]}\end{array}$ & $\begin{array}{c}0.5408 \\
{[0.5617]}\end{array}$ & $\begin{array}{c}-0.0351 \\
{[-0.0340]^{* *}}\end{array}$ \\
\hline \multicolumn{5}{|l|}{ Dividend Policy } \\
\hline Dividends/Net Income & $\begin{array}{c}0.2637 \\
{[0.2122]}\end{array}$ & $\begin{array}{c}0.2225 \\
{[0.0431]}\end{array}$ & $\begin{array}{c}0.0565 \\
{[0.0000]}\end{array}$ & $\begin{array}{c}-0.1973^{* * *} \\
{[-0.1000]^{* * *}}\end{array}$ \\
\hline Dividend/Price & $\begin{array}{c}0.0139 \\
{[0.0110]}\end{array}$ & $\begin{array}{c}0.0131 \\
{[0.0050]}\end{array}$ & $\begin{array}{c}0.0036 \\
{[0.0000]}\end{array}$ & $\begin{array}{c}-0.0095^{* * *} \\
{[-0.0036]^{* * *}}\end{array}$ \\
\hline \multicolumn{5}{|l|}{ Ownership Structure } \\
\hline $\begin{array}{l}\% \text { ownership by officers } \\
\text { and directors }\end{array}$ & $\begin{array}{c}0.1164 \\
{[0.0466]}\end{array}$ & $\begin{array}{c}0.1120 \\
{[0.0515]}\end{array}$ & $\begin{array}{c}0.0830 \\
{[0.0371]}\end{array}$ & $\begin{array}{c}-0.0276^{* * *} \\
{[-0.0068]^{* * *}}\end{array}$ \\
\hline \% ownership by CEO & $\begin{array}{c}0.0354 \\
{[0.0080]}\end{array}$ & $\begin{array}{c}0.0326 \\
{[0.0080]}\end{array}$ & $\begin{array}{c}0.0151 \\
{[0.0073]}\end{array}$ & $\begin{array}{l}-0.0177^{* * *} \\
{[-0.0010]^{* *}}\end{array}$ \\
\hline \% Blockownership & $\begin{array}{c}0.1209 \\
{[0.1060]}\end{array}$ & $\begin{array}{c}0.1416 \\
{[0.0996]}\end{array}$ & $\begin{array}{c}0.1833 \\
{[0.1697]}\end{array}$ & $\begin{array}{c}0.0653^{* * *} \\
{[0.0564]^{* * *}}\end{array}$ \\
\hline \multicolumn{5}{|l|}{ Board Composition } \\
\hline Board size & $\begin{array}{c}10.19 \\
{[10.00]}\end{array}$ & $\begin{array}{c}9.37 \\
{[9.00]}\end{array}$ & $\begin{array}{c}7.34 \\
{[7.00]}\end{array}$ & $\begin{array}{c}-2.81^{* * *} \\
{[-3.00]^{* * *}}\end{array}$ \\
\hline $\begin{array}{l}\text { Fraction of Independent } \\
\text { directors }\end{array}$ & $\begin{array}{c}0.7378 \\
{[0.7778]}\end{array}$ & $\begin{array}{c}0.7477 \\
{[0.7778]}\end{array}$ & $\begin{array}{c}0.7718 \\
{[0.8000]}\end{array}$ & $\begin{array}{c}0.0371^{* * *} \\
{[0.0223]^{* * *}}\end{array}$ \\
\hline Fraction of Insiders & $\begin{array}{c}0.2179 \\
{[0.1818]}\end{array}$ & $\begin{array}{c}0.1899 \\
{[0.1667]}\end{array}$ & $\begin{array}{c}0.2147 \\
{[0.1818]}\end{array}$ & $\begin{array}{c}0.0004 \\
{[0.0048]}\end{array}$ \\
\hline Age of board members & $\begin{array}{c}57.85 \\
{[58.93]}\end{array}$ & $\begin{array}{c}58.06 \\
{[58.80]}\end{array}$ & $\begin{array}{c}56.56 \\
{[56.85]}\end{array}$ & $\begin{array}{c}-1.61^{* * *} \\
{[-0.77]^{* * *}}\end{array}$ \\
\hline \multicolumn{5}{|l|}{ Compensation Policy } \\
\hline $\begin{array}{l}\text { Proportion of equity based } \\
\text { incentives }\end{array}$ & $\begin{array}{c}0.3402 \\
{[0.2888]}\end{array}$ & $\begin{array}{c}0.3431 \\
{[0.3189]}\end{array}$ & $\begin{array}{c}0.5308 \\
{[0.5451]}\end{array}$ & $\begin{array}{c}0.1932^{* * *} \\
{[0.2067]^{* * *}}\end{array}$ \\
\hline $\begin{array}{l}\text { Total Compensation } \\
\text { (including stock options) }\end{array}$ & $\begin{array}{c}4488.46 \\
{[3039.32]}\end{array}$ & $\begin{array}{c}5617.00 \\
{[2993.56]}\end{array}$ & $\begin{array}{c}4833.17 \\
{[3118.43]}\end{array}$ & $\begin{array}{c}79.6 \\
{[27.8]}\end{array}$ \\
\hline $\begin{array}{l}\text { Total Compensation } \\
\text { (excluding stock options) }\end{array}$ & $\begin{array}{l}2294.95 \\
{[1576.54]}\end{array}$ & $\begin{array}{c}2586.57 \\
{[1630.35]}\end{array}$ & $\begin{array}{l}1503.09 \\
{[894.07]}\end{array}$ & {$\left[-798.04^{* * *}\right.$} \\
\hline
\end{tabular}




\section{Ml Macrothink}

Asian Journal of Finance \& Accounting ISSN 1946-052X 2017, Vol. 9, No. 2

Since renegotiation/set-up by units could be costly, the benefits of separation shall exceed the related costs. In entrepreneurship-type spinoffs where spinoffs are initiated to pursue high growth opportunities available in units, it could be worthwhile to pursue the growth opportunities by setting-up their own contracts. To the contrary, in efficiency-type spinoffs where the spinoff is conducted to eliminate non-promising units, renegotiation is costly in separated units. In this second type of spinoff, there is not much room for recontracting gains for parents since the pre-spinoff contracts are already fitted contracts for the remaining parents. Table 4 shows the directions of the recontracting depending on the magnitude of growth opportunities of units. High $\mathrm{q}$ units are defiend as spunoff units whose MtoB is higheste one third of sample firms. Low q unit are those having lowest one third of MtoB.

Table 4. Growth opportunities of Units and Announcement returns

\begin{tabular}{|c|c|c|c|}
\hline & $\begin{array}{l}\text { Units' MtoB < } \\
\text { Bottom } 1 / 3 \\
\end{array}$ & $\begin{array}{c}\text { Units' MtoB > } \\
\text { Top } 1 / 3\end{array}$ & $\begin{array}{l}\text { P-Value for } \\
\text { Difference }\end{array}$ \\
\hline MtoB of Units & $\begin{array}{c}1.00 \\
{[1.02]}\end{array}$ & $\begin{array}{c}3.97 \\
{[3.03]}\end{array}$ & $\begin{array}{c}<0.0001 \\
{[<0.0001]}\end{array}$ \\
\hline MtoB of Parents & $\begin{array}{c}1.70 \\
{[1.26]}\end{array}$ & $\begin{array}{c}2.05 \\
{[1.76]}\end{array}$ & $\begin{array}{c}0.1598 \\
{[0.0020]}\end{array}$ \\
\hline Difference $\left(\mathrm{U}_{\mathrm{A}}-\mathrm{P}_{\mathrm{A}}\right)$ & $\begin{array}{c}-0.68^{* * *} \\
{[-0.26]^{* * *}}\end{array}$ & $\begin{array}{l}1.94^{* * *} \\
{[1.33]^{* * *}}\end{array}$ & $\begin{array}{c}<0.0001 \\
{[<0.0001]}\end{array}$ \\
\hline Absolute Difference & $\begin{array}{c}0.82 \\
{[0.32]}\end{array}$ & $\begin{array}{c}2.27 \\
{[1.42]}\end{array}$ & $\begin{array}{c}0.0014 \\
{[<0.0001]}\end{array}$ \\
\hline MARs $(-1,+1)$ & $\begin{array}{c}1.54 \% \\
{[1.81 \%]}\end{array}$ & $\begin{array}{l}5.20 \%{ }^{* * *} \\
{[5.85 \%]^{* * *}}\end{array}$ & $\begin{array}{c}0.0221 \\
{[0.0180]}\end{array}$ \\
\hline \multicolumn{4}{|c|}{ Difference $\left(\mathrm{U}_{\mathrm{A}}-\mathrm{P}_{\mathrm{A}}\right)$} \\
\hline \multicolumn{4}{|l|}{ Debt Policy } \\
\hline Leverage & $\begin{array}{c}-0.0607^{*} \\
{[-0.0476]^{*}}\end{array}$ & $\begin{array}{c}-0.0418 \\
{[-0.0655]}\end{array}$ & $\begin{array}{c}0.7001 \\
{[0.8595]}\end{array}$ \\
\hline Total Liability/Total Assets & $\begin{array}{c}-0.1102^{* * *} \\
{[-0.1038]^{* * *}}\end{array}$ & $\begin{array}{c}-0.0665 \\
{[-0.0905]^{*}}\end{array}$ & $\begin{array}{c}0.5130 \\
{[0.8392]}\end{array}$ \\
\hline \multicolumn{4}{|l|}{ Dividend Policy } \\
\hline Dividends/Net Income & $\begin{array}{c}-0.1762 \\
{[0.0000]^{* *}}\end{array}$ & $\begin{array}{c}0.0170 \\
{[0.0000]}\end{array}$ & $\begin{array}{c}0.3297 \\
{[0.5884]}\end{array}$ \\
\hline Dividend/Price & $\begin{array}{l}-0.0097^{* * *} \\
{[0.0000]^{* * *}}\end{array}$ & $\begin{array}{c}-0.0095^{* * *} \\
{[-0.0008]^{* * *}}\end{array}$ & $\begin{array}{c}0.9423 \\
{[0.8326]}\end{array}$ \\
\hline \multicolumn{4}{|l|}{ Ownership Structure } \\
\hline $\begin{array}{l}\% \text { ownership by officers and } \\
\text { directors }\end{array}$ & $\begin{array}{c}-0.0214^{*} \\
{[-0.0176]^{* *}}\end{array}$ & $\begin{array}{c}-0.0281^{* * *} \\
{[-0.0057]^{* * *}}\end{array}$ & $\begin{array}{c}0.6250 \\
{[0.9202]}\end{array}$ \\
\hline$\%$ ownership by CEO & $\begin{array}{l}-0.0167^{*} \\
{[0.0004]}\end{array}$ & $\begin{array}{l}-0.0265^{* *} \\
{[-0.0007]}\end{array}$ & $\begin{array}{c}0.5745 \\
{[0.3289]}\end{array}$ \\
\hline \% Blockownership & $\begin{array}{c}0.0451^{*} \\
{[0.0489]^{*}}\end{array}$ & $\begin{array}{c}-0.0358 \\
{[-0.0025]}\end{array}$ & $\begin{array}{c}0.0173 \\
{[0.0255]}\end{array}$ \\
\hline
\end{tabular}




\begin{tabular}{|l|c|c|c|}
\hline Board Composition & & & \\
\hline Board size & $-2.3182^{* * *}$ & $-1.8409^{* * *}$ & 0.3965 \\
& {$[-2.0000]^{* * *}$} & {$[-1.0000]^{* * *}$} & {$[0.4260]$} \\
\hline Fraction of Independt directors & $0.0624^{* * *}$ & -0.0048 & 0.0096 \\
& {$[0.0452]^{* * *}$} & {$[-0.0056]$} & {$[0.0388]$} \\
\hline Fraction of Insiders & -0.0077 & $0.0444^{\mathrm{a}}$ & 0.0446 \\
& {$[0.0087]$} & {$[0.0250]^{\mathrm{a}}$} & {$[0.0316]$} \\
\hline Age of board members & -1.0939 & $-1.7426^{\mathrm{a}}$ & 0.4648 \\
& {$[-0.2000]$} & {$[-0.6528]^{\mathrm{a}}$} & {$[0.4863]$} \\
\hline Compensation Policy & & & \\
\hline Proportion of equity based & $0.1770^{* * *}$ & $0.2295^{* * *}$ & 0.5374 \\
incentives & {$[0.1804]^{* * *}$} & {$[0.2202]^{* * *}$} & {$[0.4859]$} \\
\hline Total Compensation (including & 483.87 & 105.67 & 0.8798 \\
stock options) & {$[-316.60]$} & {$[73.18]$} & {$[0.6674]$} \\
\hline Total Compensation (excluding & 87.50 & -1222.53 & 0.5245 \\
stock options) & {$[-426.78]^{* * *}$} & {$[-387.51]^{* * *}$} & {$[0.8839]$} \\
\hline
\end{tabular}

From table 4, units' growth opportunities are significantly related to announcement MARs. The results show that units having low growth opportunities have restructured to have higher block ownership and higher independent outside directors, while units having high growth opportunities have larger insiders in the board. In both sub-samples, units commonly have lower dividend payment, lower ownerships, smaller board, younger board members, and higher proportion of stock option payment. The recontracting seems related to more positive market response only in spinoffs where units have highest growth opportunities.

\section{Determinant of Board Structure}

I also examine the determinants of board size and composition after spinoffs. Although thre are some significant results, more tests are needed to find causal relationships. Using firm characteristics known to be related with board size, I examine cross-sectional determinants of board size in the pre-spinoff parents $\left(\mathrm{P}_{\mathrm{B}}\right)$. Here, I only summarize the result and prvide detailed tests on the changes in board composition in table 5. In untabulated result, the number of segment and firm size are positively related with board size. The post-spinoff parents $\left(\mathrm{P}_{\mathrm{A}}\right)$ show significant path dependence on the past board size. However, the board size of units $\left(\mathrm{U}_{\mathrm{A}}\right)$ is independent from the past board size. In all regressions, firm size is only variable that are consistently associated with board size. Interestingly, Market-to-Book ratio used as proxy for firm performance and/or growth opportunities is insignificant in all regressions. Also, the previously documented negative relation between board size and the proportion of insiders are not present in our data. Similar test is conducted on board composition. In untabulated result, units' board composition is appeared to get less influence of past board, but it is still significantly path dependent. Also, Market-to-Book is insignificant in all regressions and the previously documented negative relation between board size and the proportion of insiders are not present. 


\section{Macrothink}

Lastly, I examine the change in units' board size and composition relative to post-spinoff parents $\left(\mathrm{P}_{\mathrm{A}}\right)$. All explanatory variables are computed to percentage changes. In this way, I can exclude endogeneous fixed factors of past history that might affect both remaining parents and separated units. This provides stronger test than simple change analysis of the same firm over two periods because the base number of the begining year is controlled. From table 5, dependent variables are the change in board size and the change in percentage of inside directors. Change is measured as difference between the value of spunoff units and the value of parents in the post-spinoff periods. $p$-values are reported in parenthesis. Standard errors are estimated using Huber/White robust method. All regressions include year dummy variables. All final variables are winsorized at $5 \%$ and $95 \%$ percentiles.

In model (1) of table 5, firm size is consistently associated with board size. Surprisingly, relative Market-to-Book ratio is positively related with board size. Board size is negatively related with the proportion of inside directors. Similar results are found with the inclusion of additional control variables in model (2) and in Probit model of model (3). Units having relatively higher free cash flow (proxy for agency problem) are organized with smaller board.

Regarding board composition in model (1) to (3) of table 5 , the only variable consistently significant is the change in board size. Coefficients on Market-to-Book are weakly positive in model (4) and (5). There is some evidence that ownership structure is affecting board composition. Higher CEO ownership and higher outside directors' ownership, both indicating higher incentives to behave on behalf of shareholders' interests, are associate with fewer insiders or more outsiders at the board. 
Table 5. Determinants of board size and composition

\begin{tabular}{|c|c|c|c|c|c|c|}
\hline & \multicolumn{3}{|c|}{$\begin{array}{c}\text { Change in Board size } \\
\left(\mathrm{U}_{\mathrm{A}}-\mathrm{P}_{\mathrm{A}}\right) / \mathrm{P}_{\mathrm{A}}\end{array}$} & \multicolumn{3}{|c|}{$\begin{array}{c}\text { Change in } \% \text { of insiders } \\
\left(\mathrm{U}_{\mathrm{A}}-\mathrm{P}_{\mathrm{A}}\right) / \mathrm{P}_{\mathrm{A}}\end{array}$} \\
\hline & $(1)$ & $(2)$ & $(3)$ & $(4)$ & $(5)$ & $(6)$ \\
\hline & OLS & OLS & Probit & OLS & OLS & Probit \\
\hline Relative diversity & $\begin{array}{l}0.0265 \\
(0.386)\end{array}$ & $\begin{array}{l}0.0337 \\
(0.254)\end{array}$ & $\begin{array}{l}0.0044 \\
(0.982)\end{array}$ & $\begin{array}{l}-0.1262 \\
(0.141)\end{array}$ & $\begin{array}{l}-0.1099 \\
(0.220)\end{array}$ & $\begin{array}{l}-0.1405 \\
(0.532)\end{array}$ \\
\hline Relative size & $\begin{array}{l}0.0448 \\
(0.007)\end{array}$ & $\begin{array}{l}0.0409 \\
(0.018)\end{array}$ & $\begin{array}{l}0.5344 \\
(0.000)\end{array}$ & $\begin{array}{l}0.1816 \\
(0.152)\end{array}$ & $\begin{array}{l}0.1910 \\
(0.152)\end{array}$ & $\begin{array}{l}-0.0068 \\
(0.933)\end{array}$ \\
\hline Relative leverage & $\begin{array}{l}0.0011 \\
(0.636)\end{array}$ & $\begin{array}{l}0.0019 \\
(0.447)\end{array}$ & $\begin{array}{l}-0.0004 \\
(0.983)\end{array}$ & $\begin{array}{l}-0.0150 \\
(0.073)\end{array}$ & $\begin{array}{l}-0.0132 \\
(0.141)\end{array}$ & $\begin{array}{l}-0.0112 \\
(0.635)\end{array}$ \\
\hline Relative tangible assets & $\begin{array}{l}-0.0187 \\
(0.187)\end{array}$ & $\begin{array}{l}-0.0165 \\
(0.312)\end{array}$ & $\begin{array}{l}-0.0115 \\
(0.923)\end{array}$ & $\begin{array}{l}-0.0081 \\
(0.914)\end{array}$ & $\begin{array}{l}-0.0066 \\
(0.931)\end{array}$ & $\begin{array}{l}-0.0418 \\
(0.646)\end{array}$ \\
\hline Relative MtoB & $\begin{array}{l}0.0755 \\
(0.001)\end{array}$ & $\begin{array}{l}0.0813 \\
(0.001)\end{array}$ & $\begin{array}{l}0.5246 \\
(0.000)\end{array}$ & $\begin{array}{l}0.1644 \\
(0.054)\end{array}$ & $\begin{array}{l}0.1687 \\
(0.064)\end{array}$ & $\begin{array}{l}0.0054 \\
(0.970)\end{array}$ \\
\hline Relative Freecash/Assets & & $\begin{array}{l}-0.0060 \\
(0.013)\end{array}$ & $\begin{array}{l}-0.0504 \\
(0.027)\end{array}$ & & $\begin{array}{l}-0.1929 \\
(0.238)\end{array}$ & $\begin{array}{l}-0.0257 \\
(0.247)\end{array}$ \\
\hline $\begin{array}{l}\text { Relative Industry } \\
\text { Herfindahl Index }\end{array}$ & & $\begin{array}{l}0.0165 \\
(0.392)\end{array}$ & $\begin{array}{l}0.2465 \\
(0.079)\end{array}$ & & $\begin{array}{l}-0.0020 \\
(0.978)\end{array}$ & $\begin{array}{l}0.0740 \\
(0.497)\end{array}$ \\
\hline Relative CEO ownership & & $\begin{array}{l}0.0005 \\
(0.622) \\
\end{array}$ & $\begin{array}{l}0.0027 \\
(0.476) \\
\end{array}$ & & $\begin{array}{r}-0.0044 \\
(0.030) \\
\end{array}$ & $\begin{array}{l}-0.0048 \\
(0.205)\end{array}$ \\
\hline $\begin{array}{l}\text { Relative outside director } \\
\text { ownership }\end{array}$ & & $\begin{array}{l}0.0003 \\
(0.375) \\
\end{array}$ & $\begin{array}{l}0.0020 \\
(0.569) \\
\end{array}$ & & $\begin{array}{l}-0.0016 \\
(0.105) \\
\end{array}$ & $\begin{array}{l}-0.0076 \\
(0.046)\end{array}$ \\
\hline Change in $\%$ of insiders & $\begin{array}{l}-0.0972 \\
(0.001) \\
\end{array}$ & $\begin{array}{l}-0.0906 \\
(0.002) \\
\end{array}$ & $\begin{array}{l}-0.9147 \\
(0.002) \\
\end{array}$ & & & \\
\hline Change in board size & & & & $\begin{array}{r}-1.3757 \\
(0.001) \\
\end{array}$ & $\begin{array}{r}-1.3733 \\
(0.001) \\
\end{array}$ & $\begin{array}{l}-2.1901 \\
(0.000)\end{array}$ \\
\hline Intercept & $\begin{array}{l}-0.1873 \\
(0.051)\end{array}$ & $\begin{array}{l}-0.2130 \\
(0.040)\end{array}$ & $\begin{array}{l}-0.6004 \\
(0.003)\end{array}$ & $\begin{array}{l}0.0787 \\
(0.781)\end{array}$ & $\begin{array}{l}0.0829 \\
(0.752)\end{array}$ & $\begin{array}{l}0.0330 \\
(0.873)\end{array}$ \\
\hline F-stat & $3.69^{* * *}$ & $4.17^{* * * *}$ & & $2.40^{* * *}$ & $3.38^{* * *}$ & \\
\hline Adj. $R^{2}$ & 0.212 & 0.219 & & 0.196 & 0.193 & \\
\hline $\mathrm{Chi}^{2}$ & & & $32.11^{* * *}$ & & & $28.28^{* * *}$ \\
\hline Pseudo $\mathrm{R}^{2}$ & & & 0.295 & & & 0.168 \\
\hline $\mathrm{N}$ & 208 & 205 & 205 & 205 & 208 & 207 \\
\hline
\end{tabular}

\section{Conclusion}

A firm is a nexus of contracts. These contracts represent the optimal decisions of the firm to reflect the characteristics of the firm's assets and the growth opportunities. For the firms with multiple divisions, the contracting becomes more complicated if each division is composed of assets have various growth opportunities. Examing reconstructing following spinoffs provide an unique experiment to examine a firm's policies as compared to those existed in the pre-spinoff period. I find that units adjust firm policies after they are separated from parent 


\section{Macrothink}

Asian Journal of Finance \& Accounting

ISSN 1946-052X

2017, Vol. 9, No. 2

firms. I also find some evidence that the reconstructing benefit of spin-offs is concentrated in high q units being separated. Further analysis shows that ownership structure affects board composition. Higher incentives to CEO are associate with fewer insiders and more outsiders in the board.

\section{References}

Allen, J., S. Lummer, J. McConnell, \& D. Reed (1995). Can takeover losses explain spin-off gains? Journal of Financial and Quantitative Analysis, 30, 465-485. https://doi.org/10.2307/2331273

Boone, A., L. Field, J. Karpoff, \& C. Raheja, (2007). The determinants of corporate board size and composition: An empirical analysis, Journal of Financial Economics, 85, 66-101. https://doi.org/10.1016/j.jfineco.2006.05.004

Cusatis, P., J. Miles, \& J. Woolridge (1993). Restructuring through spinoffs: The stock market evidence, Journal of Finanical Economics, 33, 293-312. https://doi.org/10.1016/0304-405X(93)90009-Z

Denis, D., \& A. Sarin (1999). Ownership and board structures in publicly traded corporations, $\begin{array}{llll}\text { Journal of Financial 187-223. } & \text { Economics, } & 52, & \text {. }\end{array}$ https://doi.org/10.1016/S0304-405X(99)00008-2

Hermalin, B., \& M. Weisbach (2003). Boards of directors as an endogenously determined institution: a survey of the economic literature, Economic Policy Review, 7-26. https://dx.doi.org/10.2139/ssrn.233111

Hite, G., \& J. Owers (1983). Security price reactions around corporate spin-off announcements, Journal of Financial Economics, 12, 409-436. https://doi.org/10.1016/0304-405X(83)90042-9

Lehn, K., S. Patro, \& M. Zhao (2007). Governance indexes and valuation: Which causes which? Journal of Corporate Finance, 13, 907-928. https://doi.org/10.1016/j.jcorpfin.2007.07.002

Wintoki, M., J. Linck, \& J. Netter (2012). Endogeneity and the dynamics of internal corporate governance, Journal of Financial Economics, 105, 581-606. https://doi.org/10.1016/j.jfineco.2012.03.005 